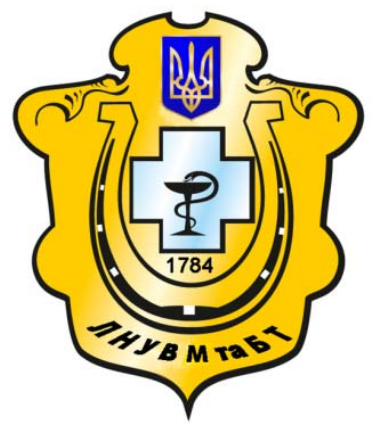

Науковий вісник Львівського національного університету ветеринарної медицини та біотехнологій імені С.3. Гжицького

Scientific Messenger of Lviv National University of Veterinary Medicine and Biotechnologies named after S.Z. Gzhytskyj

doi:10.15421/nvlvet6813

ISSN 2413-5550 print

ISSN 2518-1327 online

$\underline{\text { http://nvlvet.com.ua/ }}$

УДК $621.7: 637.5$

\title{
Використання модифікованого газового середовища та вакуумування при пакуванні і зберіганні охолодженого м'яса та напівфабрикатів з нього
}

\author{
B.М. Пасічний, О.В. Храпачов, А.І. Маринін \\ pasww1@ukr.net,khrapachov@sirius.pro, andrii_marynin@ukr.net \\ Національний університет харчових технологій, \\ вул. Володимирська, 68, м. Київ, 01601, Україна
}

\begin{abstract}
Охолоджене м'ясо є одним із найпоширеніших продуктів на споживчому ринку, який користується великим попитом, як в натуральному вигляді, так $і$ у вигляді напівфабрикатів, тому його виробництву приділяється дуже велика увага. Збереження споживчих характеристик таких продуктів протягом всього терміну їх зберігання можливе за рахунок їх пакування в полімерні багатошарові матеріали з застосуванням вакууму або модифікованого газового середовища (МГС). На доиільність вибору необхідної системи пакування впливають не тільки кінцевий споживач та бажані терміни зберігання зазначеної продукиії, а насамперед: дотримання гігієнічних вимог, температурних режимів та мінімального часу на переробку і пакування, а також властивості самого продукту. Оскільки не існує однієї універсальної системи пакування для всього асортиментного ряду м'ясопродуктів, перед тим, як виготовляти та пакувати такий продукт, виробник проводить аналіз споживчих його характеристик і властивостей, ринку збуту, зовнішнього вигляду упаковки, ї̈ призначення, умов транспортування та термінів реалізаиії і зберігання того чи іншого продукту. Якщо у виробника виникає потреба у виготовленні напівфабрикатів у вигляді відрубів, великих шматків та сімейної і пориійної упаковки, він, як правило, розглядає і пакування під вакуумом, і в модифікованому газовому середовищі. А отже для иього, обов'язково слід враховувати вплив вакууму та газової суміші на характеристики продукту та термін його реалізаиії.

Серед основних показників, які впливають на термін зберігання м'яса та м'ясопродуктів, є активніть води $\left(a_{w}\right)$ та рН. Питання зовнішнього вигляду пов'язані з пігментом міоглобіном, який, в залежності, від умов пакування (з застосуванням вакууму або модифікованого газового середовища) змінює колір м'яса. Тому при застосуванні пакування в МГС, слід послідовно підходити до підбору складу газової суміші, враховуючи вид продукту, тип обладнання, співвідношення «продукт/газ» в упаковиі тощо. А при вакуумному пакуванні охолодженого м'яса слід інформувати споживачів про можливу зміну кольору продукту під дією вакууму. Обидві системи пакування направлені на збереження свіжості та безпечності продукту протягом всього терміну його зберігання та реалізації. Вивчення процесів, які при иььоу відбуваються, зосереджене на їх иілеспрямоване застосування в м'ясопереробній галузі з метою підвищення стандартів якості такої продукиії.

Ключові слова: м'ясо та напівфабрикати, свіжість, якість, активність води, рН, міоглобін, полімерні багатошарові матеріали, термін зберігання.
\end{abstract}

\section{Использование модифицированной газовой среды и вакуумирования при упаковке и хранении охлажденного мяса и полуфабрикатов из него}

\author{
В.Н. Пасичный, О.В. Храпачев, А.И. Маринин \\ pasww1@ukr.net,khrapachov@sirius.pro, andrii_marynin@ukr.net \\ Национальный университет пищевых технологий, \\ ул. Владимирская, 68, г. Киев, 01601, Украина
}

\footnotetext{
Охлажденное мясо является одним из самых распространенных продуктов на потребительском рынке, который пользуется большим спросом, как в натуральном виде, так и в виде полуфабрикатов, поэтому его производству уделяется очень большое внимание. Сохранение потребительских характеристик таких продуктов в течение всего срока их хранения

Citation:

Pasichniy, V.M., Khrapachov, O.V., Marynin, A.I. (2016). Use of modified atmosphere and vacuuming for packing and storage of cooled meat and its semi-products. Scientific Messenger LNUVMBT named after S.Z. Gzhytskyj, 18, 2(68), 68-72.
} 
возможно за счет их упаковки в полимерные многослойные материаль с использованием вакуума или модифицированной газовой среды (МГС). На иелесообразность выбора необходимой системы упаковки влияют не только конечный потребитель и желаемые сроки хранения данной продукиии, но прежде всего: соблюдение гигиенических требований, температурных режимов и минимального времени на переработку и упаковку, а также свойства самого продукта.

Поскольку не существует одной универсальной системы упаковки для всего ассортиментного ряда мясопродуктов, перед тем, как изготавливать и упаковывать такой продукт, производитель проводит анализ его потребительских характеристик и свойств, рынка сбыта, внешнего вида упаковки, ее назначения, условий транспортировки и сроков реализации и хранения того или иного продукта. Если у производителя возникает потребность в изготовлении полуфабрикатов в виде отрубов, крупных кусков и семейной или поричинной упаковки, он, как правило, рассматривает и упаковку под вакуумом, и в модифицированной газовой среде. А значит для этого, обязательно следует учитывать влияние вакуума и газовой смеси на характеристики продукта и срок его реализации.

Среди основных показателей, которые влияют на срок хранения мяса и мясопродуктов, является активноть водьл ( $\left.a_{w}\right)$ и рН. Вопрос внешнего вида связан с пигментом миоглобином, который, в зависимости от условий упаковки (с применением вакуума или модифицированной газовой среды) меняет ияет мяса. Поэтому при использовании упаковки в МГС, следует взвешенно подходить к подбору состава газовой смеси, учитывая вид продукта, тип оборудования, соотношение «продукт/газ» в упаковке и т.д. А при вакуумной упаковке охлажденного мяса следует информировать потребителей о возможном изменении цьвета продукта под действием вакуума.

Обе системы упаковки направлены на сохранение свежести и безопасности продукта в течение всего срока его хранения и реализации. Изучение процессов, которые при этом происходят, сосредоточено на их иеленаправленное применение в мясоперерабатывающей отрасли с изелью повышения стандартов качества такой продукции.

Ключевые слова: мясо и полуфабрикаты, свежесть, качество, активность воды, рН, миоглобин, полимернье многослойные материаль, срок хранения.

\title{
Use of modified atmosphere and vacuuming for packing and storage of cooled meat and its semi-products
}

\author{
V.M. Pasichniy, O.V. Khrapachov, A.I. Marynin \\ pasww1@ukr.net, khrapachov@sirius.pro, andrii_marynin@ukr.net \\ National University of Food Technologies, \\ Volodymyrska Str., 68, Kyiv, 01601, Ukraine
}

Chilled meat is one of the most popular products on the consumer market, which is in great demand both in kind and in form of semi-finished products, that's why much attention is given to its production. Saving of consumer-oriented characteristics of such products throughout the term of their storage is possible by their packaging in multilayer polymeric materials using vacuum or modified atmosphere (MA). Feasibility of choice of the correct packaging system is affected not only by the end user and desired shelf life of these products, but also by: conformance of hygienic requirements, temperature modes and minimal time for processing and packaging, as well as by the properties of product itself.

Since there is no single universal packaging system for all range of meat products, before manufacturing and packaging of such product, a manufacturer analyzes its consumer-oriented characteristics and properties, market outlets, appearance of the packaging, its purpose, transport conditions, sell by dates and storage period of the product. If the manufacturer needs to manufacture semi-finished products in form of cuts, large pieces and family and portion packages, it typically considers vacuum packing and in modified atmosphere. So for this, it is necessary to consider the impact of vacuum and gas mixture on the characteristics of the product and its sell by time. The main parameters which affect the storage period of meat and meat products are water activity ( $\left.a_{w}\right)$ and pH. Appearance related issues are associated with the pigment myoglobin, which, depending on packing conditions (with the use of vacuum or modified atmosphere) changes the color of the meat. Therefore, using MA during packaging one should consistently approaches to the choice of gas mixture content, given the type of product, type of equipment, the ratio of "product/gas" in the package and so on. During vacuum packaging of chilled meat consumers should be informed about the possible change of color of the product under vacuum. Both packaging systems aim to save the freshness and safety of the product within its storage period and sell by date. Study of the processes that occur during this time is focused on their targeted use in the meat processing industry in order to improve the quality standards of these products.

Key words: meat and semi-finished products, freshness, quality, water activity, pH, myoglobin, polymeric multilayer materials, storage period.

В наш час при виборі м'яса переважна більшість покупців надає перевагу охолодженому продукту, цінуючи його свіжість та відсутність можливого багаторазового заморожування, що негативно впливає на його якісні показники. При цьому багато з них довіряють продукту, який виготовлений та запакований безпосередньо на м'ясопереробному підприємстві, розуміючи, що саме так можна отримати якісний продукт з стабільними споживчими властивостями.

На сьогодні відомо два варіанти пакування охолодженого м'яса та напівфабрикатів з нього з застосу- ванням багатошарових полімерних матеріалів, а саме: під вакуумом та в модифікованому газовому середовищі (МГС), кожен з яких має свої особливості, оскільки не існує одного універсального способу пакування для всього асортименту зазначеної продукції.

Якщо розрізняти за термінами зберігання м'ясопродуктів, то без сумніву, перевагу отримає пакування під вакуумом, а якщо за зовнішнім виглядом та презентабельністю продукту - найкраще підходить МГС. Слід зауважити, що пакування охолодженого м'яса під вакуумом доцільне для великошма- 
ткових напівфабрикатів, відрубів (в тому числі, як транспортне пакування), а в модифікованому газовому середовищі - для сімейної або порційної упаковки, де важливий привабливий зовнішній вигляд та зберігання первинної форми і текстури продукту, а також відсутність помітного виділення вологи.

Тому при виборі системи пакування важливо приймати до уваги наступні фактори: бажані терміни зберігання, тип продукту, що підлягає пакуванню, систему транспортування від підприємства до місця реалізації та їх віддаленість між собою (Lishnevskaya, 2007).

Пакування під вакуумом. Для отримання гарантованих термінів зберігання охолодженого м'яса та напівфабрикатів з нього окрім санітарно-гігієнічних вимог слід дотримуватись чітких температурних режимів на стадіях підготовки, розробки, знежилування та пакування напівфабрикату, а також мінімізувати час проведення даних операцій. Наприклад, для отримання високоякісного пакування свинини під вакуумом, основними вимогами є:

1. Використовувати м'ясо протягом 24 год після забою (максимум до 36 годин), що зберігалось при температурі від 0 до $1{ }^{\circ} \mathrm{C}$.

2. Перед пакуванням витримувати сировину до досягнення значення $\mathrm{pH}$ нижче 6,1 .

3. Обмежити тривалість технологічного процесу (розробка, знежилування, вакуумне пакування) - протягом години при температурі $7^{\circ} \mathrm{C}$.

4. Підтримувати температуру в центрі продукту не вище $3{ }^{\circ} \mathrm{C}$.
5. Не складувати продукти до та після обвалювання і після вакуумування.

6. Використовувати тільки те вакуумне обладнання та матеріали, що підходять для даного продукту.

7. Зберігати запакований продукт при температурі від 0 до $2{ }^{\circ} \mathrm{C}$, виключаючи відхилення від рекомендованих значень (Lishnevskaya, 2007).

Збільшення температури зберігання продукту, що запакований під вакуумом, на $4{ }^{0} \mathrm{C}$ призводить до збільшення виділення м'ясного соку та зменшення терміну придатності в два рази (Lishnevskaya, 2007). В свою чергу, процес виділення м'ясного соку пов'язаний з такими показниками, як активність води $\left(\mathrm{a}_{\mathrm{w}}\right)$ та $\mathrm{pH}$.

Встановлено, що від рівня $\mathrm{a}_{\mathrm{w}}$ залежить інтенсивність життєдіяльності мікроорганізмів, швидкість окислення, неферментативного потемніння, ферментація, структурні та структурно-механічні властивості продукту. Чим нижче значення $\mathrm{a}_{\mathrm{w}}$, тим тривалішим $\epsilon$ термін придатності продукту (Usatenko and Kryzhsjka, 2012).

Колір м'яса залежить, в основному, від наявності пігменту міоглобін. В охолодженому м'ясі присутні три різні форми пігменту (див. схему). Окислення міоглобіну є зворотнім процесом, і після відкривання вакуумної упаковки м'ясо вступає в контакт з киснем повітря та знову набуває свого звичайного яркочервоного кольору (Lishnevskaya, 2007).

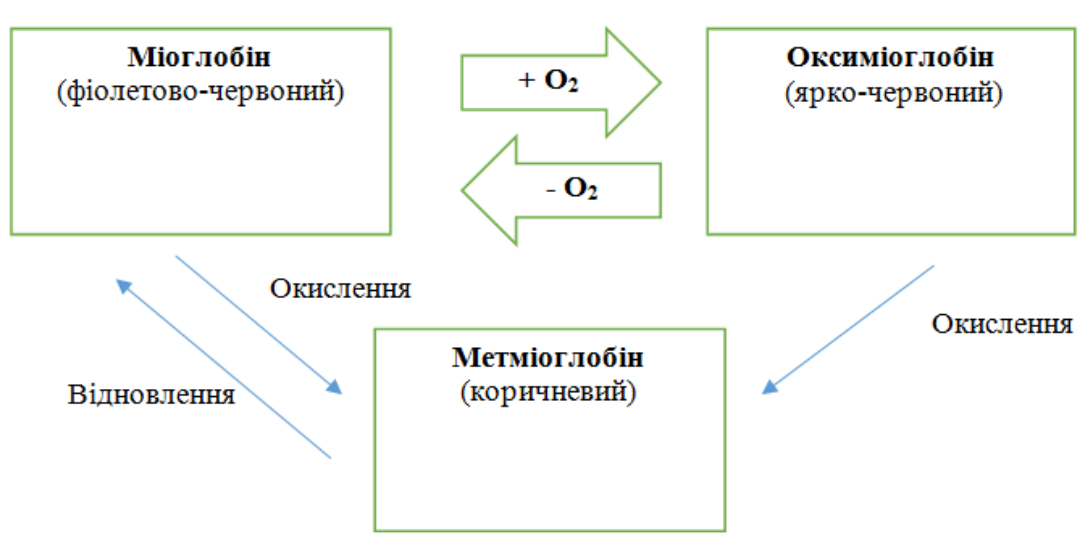

\section{Схема утворення міоглобіну, оксиміоглобіну та метміоглобіну}

Пакування в модифікованому газовому середовищі. Основні гази, що використовують в МГС технології пакування, це - двооксид вуглецю, кисень та азот (іноді замість азоту використовується аргон), кожен $з$ яких відіграє визначену роль в суміші, яку в свою чергу, розрізняють на двох- або трьохкомпонентну (Stavtsevoy, 2007).

Двооксид вуглецю ( $\left.\mathrm{CO}_{2}\right)$ володіє сильними інгібіторними властивостями та уповільнює розвиток мікроорганізмів , в тому числі і найбільш поширених Pseudomonas. При взаємодії $\mathrm{CO}_{2} 3$ водою, що входить до складу продукту, утворюється вугільна кислота, яка призводить до деякого зниження рН. Але при великих концентраціях $\mathrm{CO}_{2}$ та високій вологості продукту можливе утворення на його поверхневому шарі кислого присмаку (Stavtsevoy, 2007).

Aзот $\left(\mathrm{N}_{2}\right)$ - практично інертний газ, малорозчинний у воді та жирі. Використання даного газу здійснюється 3 метою максимально можливого видалення залишків кисню, тим самим протидіючи розвитку анаеробних бактерій, а також запобігаючи окисленню жирів.

Кисень $\left(\mathrm{O}_{2}\right)$ відповідає за процеси окислення та прогіркання жирів та псування продуктів в результаті росту аеробних бактерій, тому необхідно уникати його присутності в упаковках. Але іноді наявність 
кисню в газовій суміші - вимушена необхідність, наприклад, при пакуванні охолодженого м'яса в МГС. Зберігання ярко-червоного кольору яловичини, що асоціюється 3 іiі свіжістю і $є$ наслідком окислення міоглобіну 3 його перетворенням в оксиміоглобін, потребує присутності $\mathrm{O}_{2}$ в упаковці в кількості до
$80 \%$ (Klimanov and Shugurova, 2006; Lishnevskaya, 2007; Stavtsevoy, 2007).

Виходячи 3 індивідуальних властивостей продуктів, для них рекомендують різний склад МГС та умови зберігання (табл. 1) (Maslikov, 2008).

\begin{tabular}{|c|c|c|c|c|c|}
\hline \multirow{2}{*}{ Продукт } & \multicolumn{3}{|c|}{ Склад МГС, \% } & \multirow{2}{*}{$\begin{array}{c}\text { Температура збері- } \\
\text { гання, }{ }^{0} \mathrm{C}\end{array}$} & \multirow{2}{*}{$\begin{array}{c}\text { Tермін зберігання, } \\
\text { діб }\end{array}$} \\
\hline & $\mathrm{O}_{2}$ & $\mathrm{CO}_{2}$ & $\mathrm{~N}_{2}$ & & \\
\hline \multirow{2}{*}{ Свіже червоне м'ясо } & $60-85$ & $15-40$ & $0-10$ & $0-2$ & $10-15$ \\
\hline & $60-70$ & $20-25$ & $5-10$ & $0-2$ & $12-15$ \\
\hline \multirow{3}{*}{ М'ясо птиці } & - & 20 & 80 & $0-2$ & $15-20$ \\
\hline & $20-30$ & $20-30$ & $40-60$ & $0-2$ & $15-20$ \\
\hline & $40-50$ & $20-30$ & $20-30$ & $0-2$ & $15-20$ \\
\hline Свіжий м’ясний фарш & $30-40$ & $30-40$ & $30-40$ & $0-2$ & $8-12$ \\
\hline
\end{tabular}

Середній термін зберігання охолодженого м'яса та напівфабрикатів 3 нього в модифікованому газовому середовищі становить від 7 до 14 днів і залежить від багатьох описаних вище факторів. Такий варіант пакування ідеально підходить для роздрібної упаковки, коли продукт знаходиться на вітринах самообслуговування (Shubina, 2015).
Більш детальні умови та терміни зберігання охолодженого м'яса та напівфабрикатів з нього (як під вакуумом, так і в модифікованому газовому середовищі), згідно діючої нормативно-технологічної документації, наведені в таблиці 2.

\begin{tabular}{|c|c|c|c|c|c|c|c|}
\hline \multirow{4}{*}{$\begin{array}{c}\text { Види напівфа- } \\
\text { брикатів, спо- } \\
\text { сіб розробки та } \\
\text { обробки }\end{array}$} & \multicolumn{7}{|c|}{ Термін придатності, діб, не більше } \\
\hline & \multicolumn{3}{|c|}{$\begin{array}{c}\text { в охолодженому стані від } 0{ }^{\circ} \mathrm{C} \text { до } \\
4^{\circ} \mathrm{C}\end{array}$} & \multicolumn{4}{|c|}{ в замороженому стані } \\
\hline & \multirow[b]{2}{*}{$\begin{array}{c}\text { під } \\
\text { ваку- } \\
\text { умом }\end{array}$} & \multirow{2}{*}{$\begin{array}{c}\text { під ваку- } \\
\text { умом } 3 \\
\text { наступ- } \\
\text { ним про- } \\
\text { веденням } \\
\text { термоз- } \\
\text { сідання }\end{array}$} & \multirow[b]{2}{*}{$\begin{array}{c}\text { в сере- } \\
\text { довищі } \\
\text { захисно- } \\
\text { го газу }\end{array}$} & \multicolumn{2}{|c|}{$\begin{array}{c}\text { під вакуумом або під ва- } \\
\text { куумом } 3 \text { наступним про- } \\
\text { веденням термозсідання }\end{array}$} & \multicolumn{2}{|c|}{$\begin{array}{l}\text { в середовищі захи- } \\
\text { сного газу }\end{array}$} \\
\hline & & & & $\begin{array}{l}\text { від мі- } \\
\text { нус } \\
5^{\circ} \mathrm{C} \text { до } \\
\text { мінус } \\
10{ }^{\circ} \mathrm{C}\end{array}$ & $\begin{array}{c}\text { від мінус } \\
15^{\circ} \mathrm{C} \text { до мі- } \\
\text { нус } 18^{\circ} \mathrm{C}\end{array}$ & $\begin{array}{l}\text { від мі- } \\
\text { нус } \\
5^{\circ} \mathrm{C} \text { до } \\
\text { мінус } \\
10^{\circ} \mathrm{C}\end{array}$ & $\begin{array}{c}\text { від } \\
\text { мінус } \\
15^{\circ} \mathrm{C} \\
\text { до мі- } \\
\text { нус } 18 \\
{ }^{\circ} \mathrm{C}\end{array}$ \\
\hline \multicolumn{8}{|c|}{ Із яловичини, телятини, свинини та баранини натуральні: } \\
\hline $\begin{array}{l}\text { - великошмат- } \\
\text { кові } \\
\text { - порційні } \\
\text { - дрібношмат- } \\
\text { кові } \\
\text { - м'ясокісткові }\end{array}$ & $\begin{array}{l}14 \\
14 \\
10 \\
10\end{array}$ & $\begin{array}{l}28 \\
- \\
21\end{array}$ & $\begin{array}{l}10 \\
10 \\
10 \\
10\end{array}$ & $\begin{array}{l}60 \\
60 \\
60 \\
30\end{array}$ & $\begin{array}{l}180 \\
180 \\
180 \\
120\end{array}$ & $\begin{array}{c}- \\
160 \\
160 \\
45\end{array}$ & $\begin{array}{c}- \\
180 \\
180 \\
120\end{array}$ \\
\hline \multicolumn{8}{|c|}{ Із яловичини, телятини, свинини та баранини, підготовлені до кулінарної обробки: } \\
\hline $\begin{array}{l}\text { - солені } \\
\text { - в соусі } \\
\text { - зі спеціями }\end{array}$ & $\begin{array}{c}10 \\
12 \\
6\end{array}$ & $\begin{array}{l}- \\
- \\
-\end{array}$ & $\begin{array}{r}12 \\
15 \\
8\end{array}$ & $\begin{array}{l}90 \\
90 \\
60\end{array}$ & $\begin{array}{l}160 \\
160 \\
120\end{array}$ & $\begin{array}{l}90 \\
90 \\
60\end{array}$ & $\begin{array}{l}160 \\
160 \\
120\end{array}$ \\
\hline \multicolumn{8}{|c|}{ Із яловичини, телятини, свинини, баранини, рубані } \\
\hline $\begin{array}{l}\text { - фарши м'ясні, } \\
\text { м'ясо-рослинні }\end{array}$ & - & - & 10 & 120 & 180 & 120 & 180 \\
\hline
\end{tabular}

\section{Висновки}

Обізнаність кожного споживача стимулює виробників виготовляти якісний та конкурентний продукт, що користується широким попитом, тим самим підвищуючи рівень довіри до м'ясопереробних підприємств. Виготовлення якісних м'ясопродуктів нерозривно пов'язане з використання новітніх технологій та систем пакування, що дозволяє зберегти якісні споживчі властивості продукту протягом всього терміну його зберігання. А от яким буде даний термін - залежить від правильного підходу до вивчення процесів, що проходять (або можуть проходити) в продукті, так як деякі небажані з них можна попередити, а необхідні - підтримати. Вивчення даних процесів допомагає вдосконаленню технології виробництва охолодженого м'яса та напівфабрикатів 3 нього з врахуванням оптимальних умов та систем пакування.

\section{Бібліографічні посилання}

Lishnevskaya, I. (2007). «Okhlazhdenka». Osobennosti upakovki. Myasnye tekhnologii. 4, 12-13 (in Russian). 
Usatenko, N.F., Kryzhsjka, T.A. (2012). Zberighannja ta pererobka produkciji. Vykorystannja pokaznyka «aktyvnistj vody» $\mathrm{v}$ tekhnologhiji vyrobnyctva m'jasoproduktiv. Visnyk aghrarnoji nauky. 5, 62-65 (in Ukrainian).

Stavtsevoy, N.A. (2007). Upakovka myasnykh produktov v MGS: [intervyu s rukovoditelem napravleniya pishchevykh gazov kompanii «Linde Gaz» ...]. 10, 36-40 (in Russian).
Klimanov, A.K., Shugurova, T.B. (2006). Kompleksnye resheniya proizvodstva i upakovki polufabrikatov. Myasnaya industriya. 9, 39-42 (in Russian).

Maslikov, M.M. (2008). Vykorystannja MGhS dlja zberighannja m'jasoproduktiv. Mjasnoe delo. 10, 5657 (in Ukrainian).

Shubina, G. (2015). Tekhnologicheskie aspekty upakovki okhlazhdennogo myasa i myasnykh polufabrikatov $\mathrm{v}$ MGS. Myasnoy biznes. 6, 39-40.

Стаття надійшла до редакиії 23.09.2016 